\title{
Bioremediation of Waste Water from Cadmium Pollution using Silicon Dioxide Nanoparticles and Fungal Biomasses
}

\author{
Eman Abdullah M. Ali ${ }^{1 *}$ (D) Mohsen A. Sayed $^{1}(\mathbb{D})$ Tahany M.A. Abdel-Rahman $^{1}$ (D), \\ Ali M. Hussein ${ }^{2}$ (D) and Rabab Hussein ${ }^{2}$ D \\ ${ }^{1}$ Botany and Microbiology Department, Faculty of Science, Cairo University, 12613, Giza, Egypt. ${ }^{2}$ Basic Science \\ Department, Faculty of Engineering, Misr University for Science and Technology, Egypt.
}

\begin{abstract}
The aim of this paper was cadmium removal from waste water using $\mathrm{SiO}_{2}$ nanoparticles and fungal biomasses. Five treatments were used for cadmium removal. They were inactivated mycelia of Cladosporium sphaerospermum (CLA) and Fusarium oxysporum (FUS), $\mathrm{SiO}_{2}$ nanoparticles (N-Si) and their combinations (N-Si-CLA and N-Si-FUS). The biosorbents natures and combinations were examined by Fourier Transform Infrared (FT-IR) and Scanning Electron Microscope (SEM) where close attachments between combined biosorbents were detected. Different factors affecting cadmium biosorption capacity were tested. It was found that (N-Si-CLA) and (N-Si-FUS) were the most potent biosorbents at pH 7. Thirty minutes contact time exerted maximum sorption capacity. Initial cadmium concentration was optimum at $0.5 \mathrm{~mol}^{-1}$ for highest biosorption capacity. $\mathrm{Ca}^{2+}$ displayed synergistic interfering more than $\mathrm{Na}^{+}$and $\mathrm{K}^{+}$, respectively. Two real waste water samples collected from two factories were tested to depollute cadmium using the five sorbents. (N-Si-CLA) and (N-Si-FUS) were the most potent adsorbents, where $\mathbf{6 5 . 7 3} \%$ and $\mathbf{5 4 . 3 0 \%}$ removed in the first sample and $61.33 \%$ and $56.50 \%$ in the second one, respectively. From the results, it was concluded that bioremediation of cadmium from waste water was possible by using $\mathrm{SiO}_{2}$ nanoparticles and fungal biomasses with high efficiency of their combinations.

Keywords: Silicon dioxide nanoparticles, Waste water, Cadmium pollution, Bioremediation, Heat inactivated fungal biomasses, Immobilization.
\end{abstract}

*Correspondence: emanali@sci.cu.edu.eg; +201222643685

(Received: 28 July 2019; accepted: 16 September 2019)

Citation: Eman Abdullah M. Ali, Mohsen A. Sayed, Tahany M.A. Abdel-Rahman, Ali M. Hussein and Rabab Hussein, Bioremediation of Waste Water from Cadmium Pollution using Silicon Dioxide Nanoparticles and Fungal Biomasses, J Pure Appl Microbiol., 2019; 13(3):1561-1570. https://doi.org/10.22207/JPAM.13.3.29

C The Author(s) 2019. Open Access. This article is distributed under the terms of the Creative Commons Attribution 4.0 International License which permits unrestricted use, sharing, distribution, and reproduction in any medium, provided you give appropriate credit to the original author(s) and the source, provide a link to the Creative Commons license, and indicate if changes were made. 


\section{INTRODUCTION}

In aquatic environment, heavy metals are reported as the main inorganic pollutant even if they present at small concentrations because they can lead to a significant risk to public health and environment due to their non-biodegradability, poisonousness, carcinogenicity and subsequent bio-magnifications ${ }^{1,2}$. Heavy metal such as $\mathrm{Pb}$, $\mathrm{Hg}, \mathrm{Cd}, \mathrm{Cu}, \mathrm{Cr}, \mathrm{As}$ and $\mathrm{Zn}$ are serious pollutants to human health.

Cadmium has many toxic effects on microorganisms and can denature protein, destruct nucleic acid, prevent cell division and transcription and inhibit nitrogen and carbon mineralization. However arsenic metal can cause cancer; mercury metal can cause genetic damage and mutations, while lead, mercury and copper metals can cause bone and brain damage ${ }^{3}$.

Because of high mobility of cadmium in the environment, it can be considered as one of the highest toxic element ${ }^{4}$. It can also lead to bone degeneration, renal dysfunction, hypertension, liver damage and lung insufficiency in humans ${ }^{5}$. The United Kingdom Red List Substances ${ }^{6}$ has been recorded cadmium as dangerous metal in the environment. Furthermore, the US Environmental Protection Agency ${ }^{7}$ has categorized cadmium ions as group B1 carcinogen. Waste water produced from industry, mining plants, alloys, fertilizers, batteries and plastic manufacturing were considered as the main sources of cadmium pollution. Incineration of municipal wastes and fossil fuels are the major sources of cadmium in the air. Another serious origin of cadmium exposure is smoking 5 . Agency for Toxic Substances and Disease Registry ATSDR ${ }^{8}$ claimed that smokers have in their bodies about twice cadmium amount than do nonsmokers. They also reported that Cadmium has acute (shortterm) effects on human lungs through inhalation exposure, such as pulmonary irritation. Chronic oral exposure to cadmium or inhalation causes kidney disease due to accumulation of cadmium in the kidneys. Animal studies provide evidence that oral exposure and inhalation of cadmium has adverse progressive effects, such as small fetal weight, skeletal abnormalities, interference with fetal metabolism, poor neurological development and some reproductive effects, such as testicular damage and decreased reproduction ${ }^{8,9,10}$.
Heavy metals exist in waste waters have severe effects on biological systems. These elements do not decompose and tend to biomagnify in human by food chain. Hence, there is a necessity to eliminate heavy metals from the aquatic ecosystem ${ }^{11}$. Removal of heavy metals from waste water mainly done by the osmosis of solution, the precipitated ability of metals and chromatographic exchange of ions. All these techniques are expensive especially at low metal concentrations and generally non selective and inefficient ${ }^{12,13}$. So, bioremediation of heavy metals from polluted environments through microbial biosorption uptake is considered as a save efficient technique.

Biosorption process is defined as an interaction between metal ion and binding sites of biomass through numerous mechanisms comprising ion exchange, complexation, and electrostatic attraction ${ }^{14,15}$. Biosorption by employing non-living microbial biomass was more effective and favorable for elimination and remediation of heavy metals from aqueous media $15,16,17,18,19$. Various adsorbents such as silica gel, graphite oxide and activated carbon can be used in the purification of water from pollutants ${ }^{20,21}$.

Nanomaterial has several applications, such as technological and environmental solar energy conversion, medicine, catalysis and water treatments ${ }^{22,23}$. Numerous studies have considered nano-particles, especially metal oxides, as effective adsorbents in the cleanup of environmental contaminants, because nanoparticles can penetrate into the contamination zone where micro-particles cannot.

Moreover, Immobilized cells are commonly easier to handle because they need less complex separation systems, permit a great biomass density to be kept and offer more chance for reuse and recovery. The entrapment of non-living microbial cells on synthetic or natural polymers improved the performance and biosorptive capacity and increasing the life time of these biosorbents for regeneration and re-cycling numerous times ${ }^{24,25,26,27}$.

Through the present decade, immobilized fungal cells pay an attention in bioremediation of heavy metals such as cadmium from waste 
water ${ }^{15}$. The applications of immobile fungi for cadmium removal from aqueous solution were studied under the effects of contact time, initial concentration, $\mathrm{pH}$, agitation rate and temperature ${ }^{28}$. Microbial immobilization was achieved by differed techniques and polymers, for example, usage of calcium alginate and entrapment by different matrices. These immobile cells proved to have high biosorption capacity toward waste water pollutants with toxic metals such as $\mathrm{Mn}^{2+}, \mathrm{Cu}^{2+}, \mathrm{Ni}^{2+}, \mathrm{Pb}^{2+}, \mathrm{Fe}^{3+}, \mathrm{Cd}^{2+}$ and $\mathrm{Zn}\left(\mathrm{II}^{29}\right.$.

The aim of this study was the depollution of cadmium from waste water using silicon dioxide nanoparticles, heat inactivated fungal biomass and their combinations.

\section{MATERIALS AND METHODS \\ Collection of waste water samples}

Two waste water samples were collected in sterile bottles from General Motors Factory (S1) (6 October City, Egypt) and Egyptian Plastic and Electricity Factory (S2) (Cairo, Egypt).

\section{Isolation of fungi from waste water samples}

Fungi were isolated from waste water using pour plate method. Glucose peptone medium was used as an isolation medium. It composed of $\left(\mathrm{g} \mathrm{l}^{-1}\right) 10.0$ glucose; $0.5 \mathrm{MgSO}_{4} .7 \mathrm{H}_{2} \mathrm{O}$; $1.0 \mathrm{KH}_{2} \mathrm{PO}_{4} ; 5.0$ peptone and 20.0 agar and $\mathrm{pH}$ of $6.7^{30}$. The inoculated Plates with one $\mathrm{ml}$ waste water were incubated at $30^{\circ} \mathrm{C}$ for 7 days. The growing fungi were counted and identified according to Moubasher ${ }^{31}$.

\section{Production of thermal inactivated fungal biomasses}

Glucose peptone broth was used to grow the waste water fungal isolates; the inoculated cultures were incubated for $7 \mathrm{~d}$ at $30^{\circ} \mathrm{C}$ then centrifuged. The biomass washed using distilled water then dried in an oven at $80^{\circ} \mathrm{C}$ till constant weight to inactivate cells. The dried cells were grinded into powder and stored at $25^{\circ} \mathrm{C}$ in vacuum desiccators.

Preparation of thermal inactivated fungal biomass combined with silicon dioxide nanoparticles

Mixtures of silicon dioxide with either Cladosporium sphaerospermum or Fusarium oxysporum were prepared as follows: $2.5 \mathrm{~g}$ of heat inactivated fungal biomass was mixed with dried nanopowdered of $\mathrm{SiO}_{2}(10-20 \mathrm{~nm}$ BET) of the same weight and $5 \mathrm{ml}$ distilled water and left for $15 \mathrm{~min}$. The mixture put in an oven at $80^{\circ} \mathrm{C}$ till constant weight. The process of mixing and drying was repeated successively for 5 times $^{32}$.

SEM and FT-IR examination of the combined mixtures

Scanning Electron Microscope (SEM) (JEOL-JSM-5600LV-Japan) was used for studying the morphology and nature of the surface and for description of heat inactivated fungal biomass before and after combination with silicon dioxide nanoparticles. This combination was also emphasized by Fourier Transform Infrared (FT-IR) spectra by using SHIMADZU FT-IR Spectrophotometer (FT-IR 4100- JASCO-japan).

Factors affecting biosorption capacity of cadmium from aqueous solution

Effect of $\mathrm{pH}$ on $\mathrm{Cd}(\mathrm{II})$ sorption capacity were investigated using $15 \mathrm{mg}$ of the dry solid sorbent either $\mathrm{SiO}_{2}$ nanoparticles (N-Si), Cladosporium sphaerospermum (CLA), Fusarium oxysporum (FUS), or their combinations ( $\mathrm{N}-\mathrm{Si}$ $\mathrm{CLA}$ ) and (N-Si-FUS) with one $\mathrm{ml}$ of $0.1 \mathrm{M} \mathrm{Cd}^{2+}$ solution and add nine $\mathrm{ml}$ of buffer solutions to adjust different pHs at 3.0, 5.0 and 7.0. These sorption mixtures were kept under shaking for $30 \mathrm{~min}$, filtered and washed with $30 \mathrm{ml}$ distilled water ${ }^{32}$. Complexmetric titration process against 0.01 M EDTA was done to determine the residual $\mathrm{Cd}^{2+}$ in the filtrate. Triplicate titrations were done for each experiment. The sorption capacity (q) was calculated as follow:

$$
\mathrm{q}=\left(\mathrm{C}_{\mathrm{o}}-\mathrm{C}\right) \mathrm{V} \times 10^{3} / \mathrm{m}
$$

Where, $q\left(\mu \mathrm{mol} \mathrm{g}^{-1}\right)$ is the amount of cadmium adsorbed per gram of sorbent, $\mathrm{C}_{0}\left(\mathrm{moll}^{-1}\right)$ initial $\mathrm{Cd}^{2+}$ concentration, $\mathrm{C}\left(\mathrm{mol} \mathrm{l}^{-1}\right)$ final residual $\mathrm{Cd}^{2+}$ concentration, $\mathrm{V}(\mathrm{ml})$ volume of the sorption mixture and $\mathrm{m}(\mathrm{g})$ biomass of sorbent.

Another factors that affect $\mathrm{Cd}$ (II) sorption capacity were also studied. The effect of contact time between sorbents was investigated at different periods $(10,20,30 \mathrm{~min})$ under shaking, the effect of initial $\mathrm{Cd}$ (II) concentration was studied $\left(0.025,0.1,0.5 \mathrm{~mol}^{-1}\right)$ and the effect of metal interference on $\mathrm{Cd}$ (II) sorption capacity was investigated using different metals such as $\mathrm{Na}^{+}, \mathrm{Ca}^{2+}$ and $\mathrm{K}^{+}$, in equimolar concentration. In all experiments, the residual $\mathrm{Cd}^{2+}$ concentrations in filtrate was determined using EDTA titration and 
Cd(II) sorption capacities were calculated from the previous equation. Each experiment was done in triplicates and results given are the mean values. Cadmium bioremediation from real waste water samples

Two samples of waste water (item 2.1) were analyzed for determination of cadmium concentration by the atomic absorption spectrophotometer (JASCO V-630- Japan). The previously mentioned sorption experiment procedure was carried out at $0.0006 \mathrm{~mol} \mathrm{l}^{-1}$ and
$0.00152 \mathrm{~mol} \mathrm{l}^{-1}$ as initial cadmium concentration and at the optimum condition of $\mathrm{pH}$, contact time and sorbent dosage. The cadmium sorption capacity after sorption process was determined by EDTA titration.

\section{RESULTS}

Isolation of fungi from waste water samples

Only two fungal species were detected in the two waste water samples. These tolerant
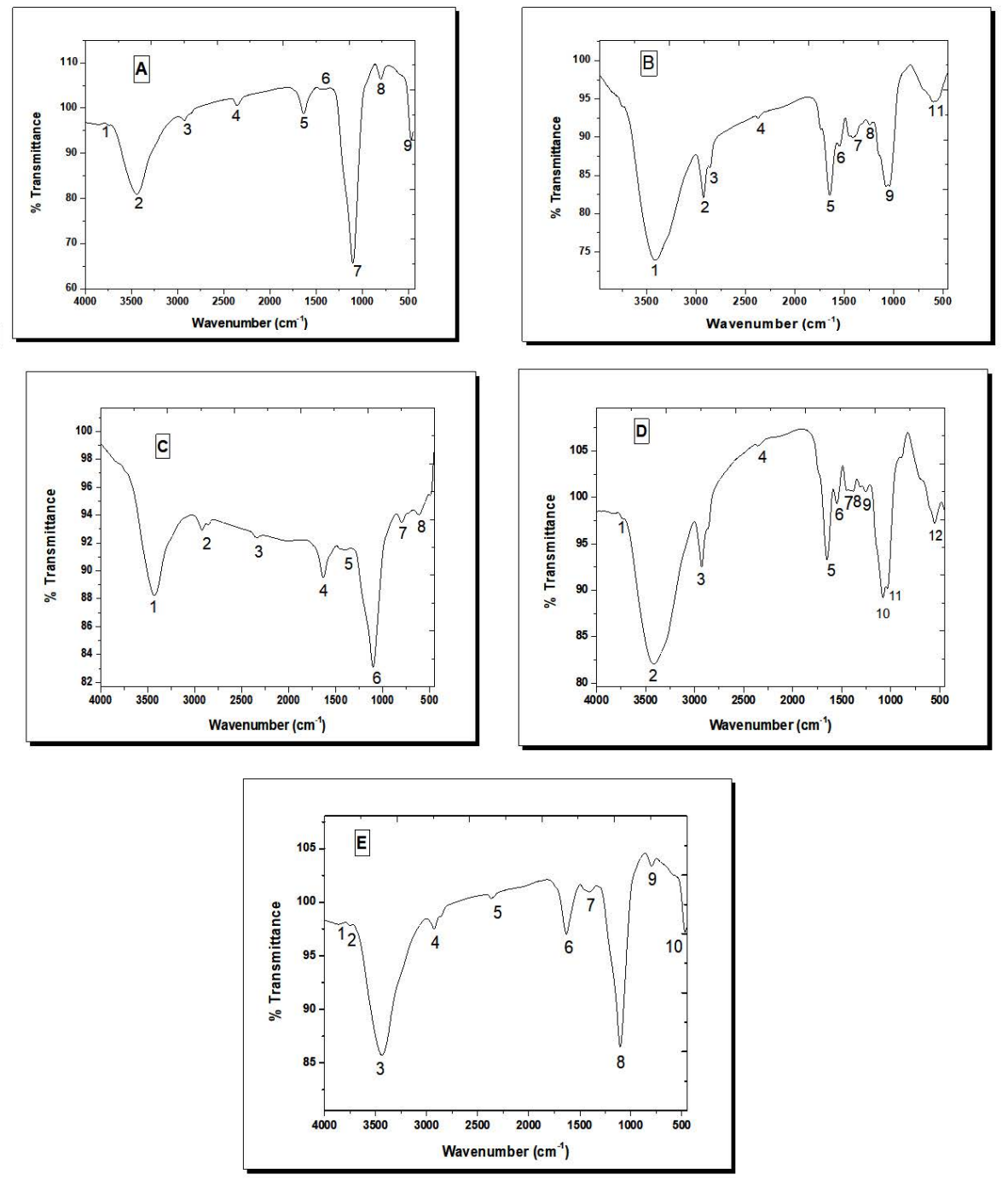

Fig. 1. FT-IR spectra. (A) Silicon dioxide nanoparticles (N-Si), (B) Heat inactivated Cladosporium sphaerospermum (CLA), (C) Silicon dioxide nanoparticles combined with heat inactivated $C$. sphaerospermum $\left(\mathrm{N}^{-} \mathrm{Si}^{-} \mathrm{CLA}\right)$, (D) Heat inactivated Fusarium oxysporum (FUS) and (E) Silicon dioxide nanoparticles combined with heat inactivated $F$. oxysporum ( $\left.\mathrm{N}^{-} \mathrm{Si}^{-} \mathrm{FUS}\right)$ 
species were Cladosporium sphaerospermum and Fusarium oxysporum.

\section{FTIR and SEM examination of the biosorbents}

The ability of heat inactivated fungal mycelium to be adsorbed on the surface of $\mathrm{SiO}_{2}$ nanoparticles were confirmed by FT-IR and SEM.
Many bands were appeared when $\mathrm{Sio}_{2}$ particles were studied by FT-IR (Fig 1A). The examinations of fungi by FT-IR were characterized by several peaks as shown in Fig 1 ( $B$ and $D)$. The several peaks of silicon dioxide nano particles combined with heat inactivated fungi were displayed in Fig 1 ( $C$ and $E$ ).
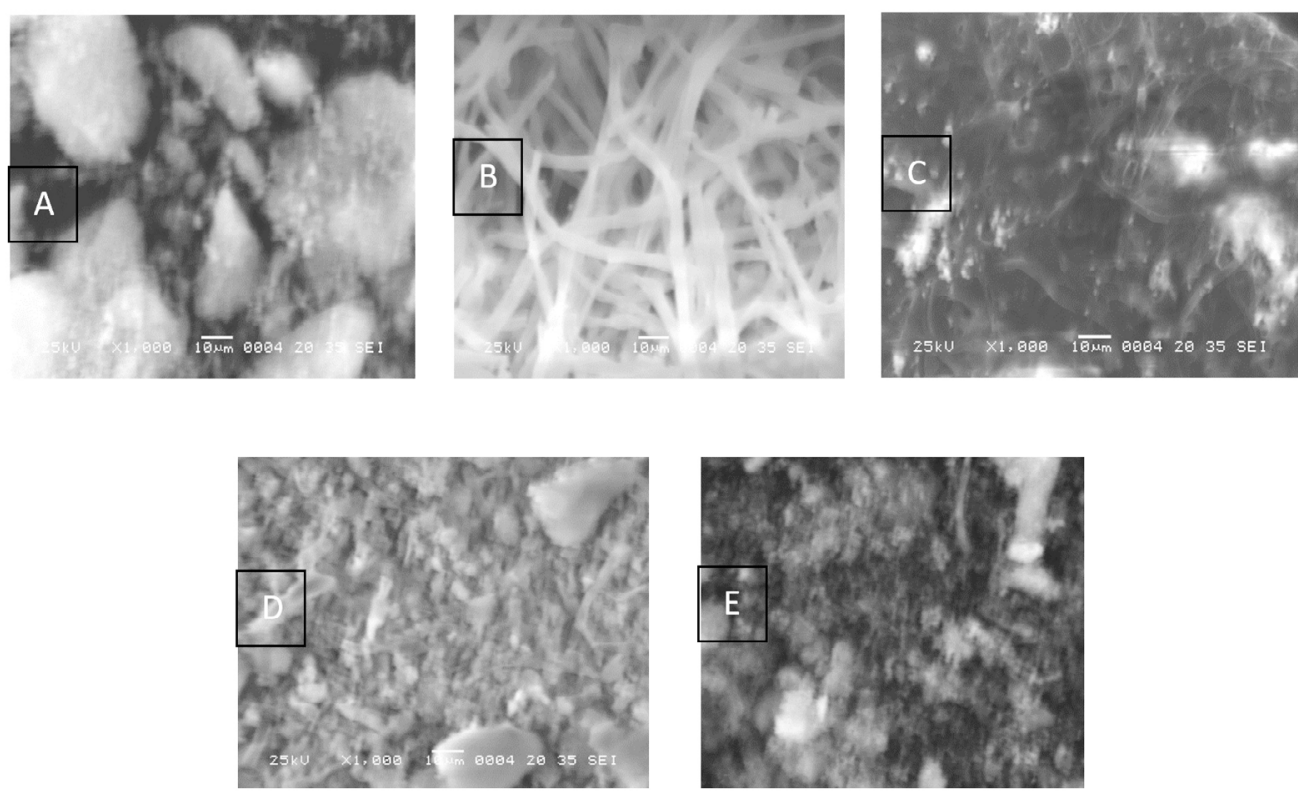

Fig. 2. SEM images of various sorbents at magnification of 1000 x. (A) Silicon dioxide nanoparticles (N-Si), (B) Heat inactivated Cladosporium sphaerospermum (CLA), (C) Heat inactivated Fusarium oxysporum (FUS), (D) Silicon dioxide nanoparticles combined with heat inactivated Cladosporium sphaerospermum (N-Si-CLA) and (E) Silicon dioxide nanoparticles combined with heat inactivated Fusarium oxysporum (N-Si-FUS)

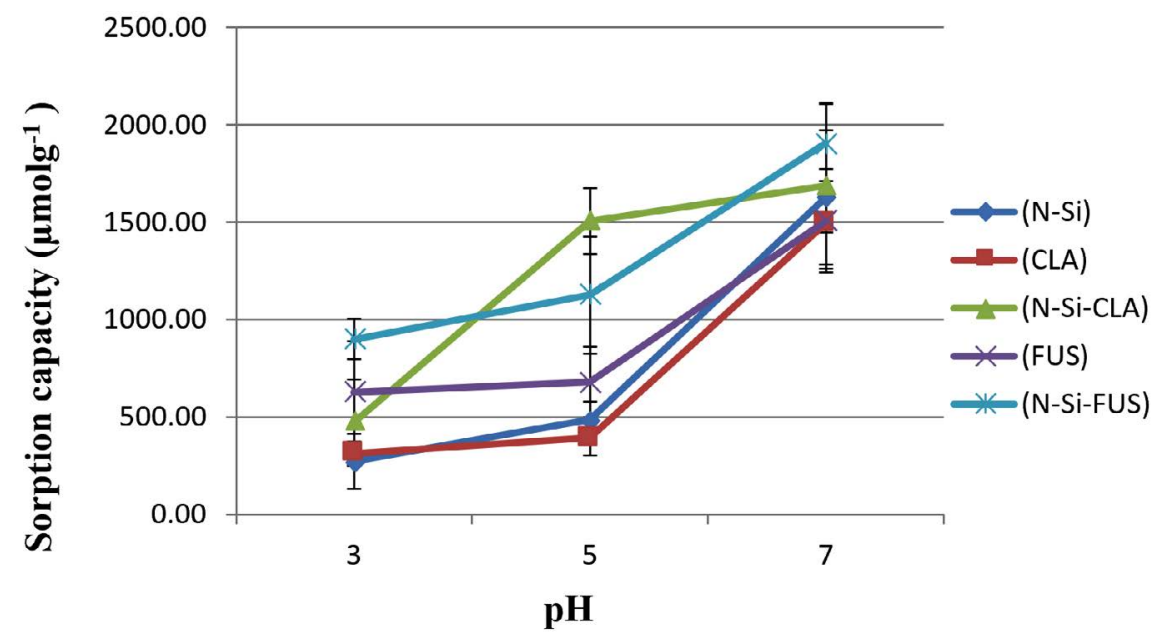

Fig. 3. Effect of pH on cadmium (II) sorption capacity. ( $\downarrow$ ) Silicon dioxide nanoparticles (N-Si), ( $\mathbf{\square}$ ) Heat inactivated Cladosporium sphaerospermum (CLA), ( $\mathbf{\Delta}$ ) Silicon dioxide nanoparticles combined with heat inactivated Cladosporium sphaerospermum (N-Si-CLA), (X) Heat inactivated Fusarium oxysporum (FUS) and (Ж) Silicon dioxide nanoparticles combined with heat inactivated Fusarium oxysporum (N-Si-FUS) 
Surfaces of silicon dioxide nanoparticles and heat inactivated fungi were examined using SEM (Fig 2). Silicon dioxide nanoparticles were clearly showed as regular and homogenous particles distributed in uniform shapes (Fig 2A). Combinations of sorbents were showed in Fig 2D and $\mathrm{E}$.

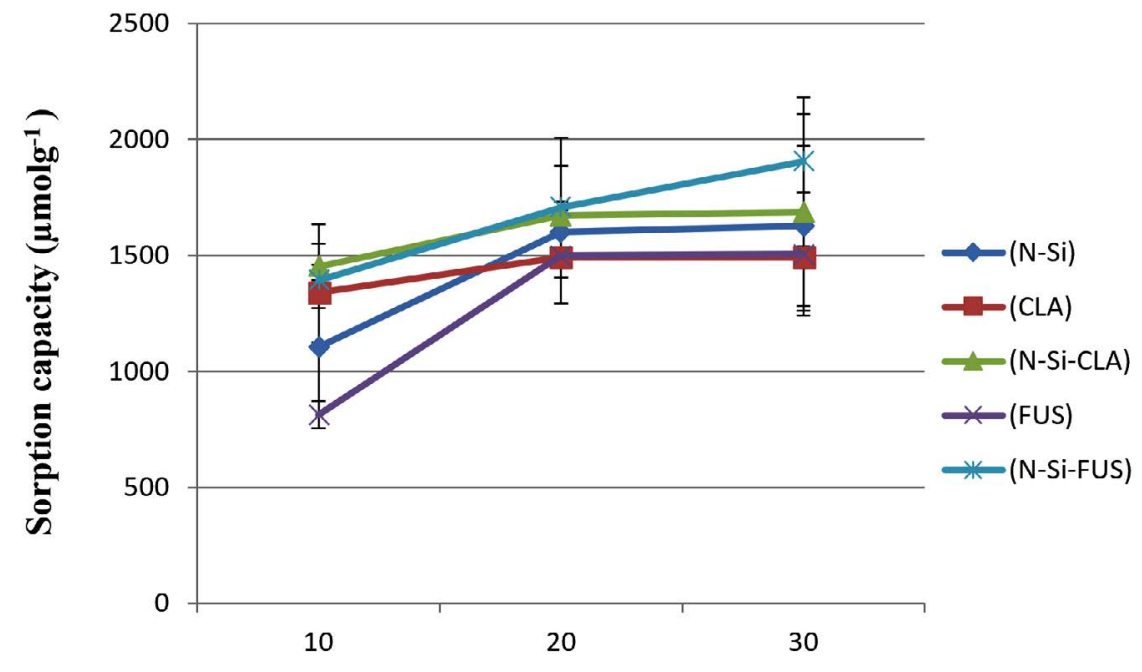

Time (min.)

Fig. 4. Effect of contact time on cadmium (II) sorption capacity by different sorbents. ( $\downarrow$ ) Silicon dioxide nanoparticles (N-Si), ( $\mathbf{\square})$ Heat inactivated Cladosporium sphaerospermum (CLA), ( $\mathbf{\Delta}$ ) Silicon dioxide nanoparticles combined with heat inactivated Cladosporium sphaerospermum (N-Si-CLA), (X) Heat inactivated Fusarium oxysporum (FUS) and (Ж) Silicon dioxide nanoparticles combined with heat inactivated Fusarium oxysporum (N-Si-FUS)

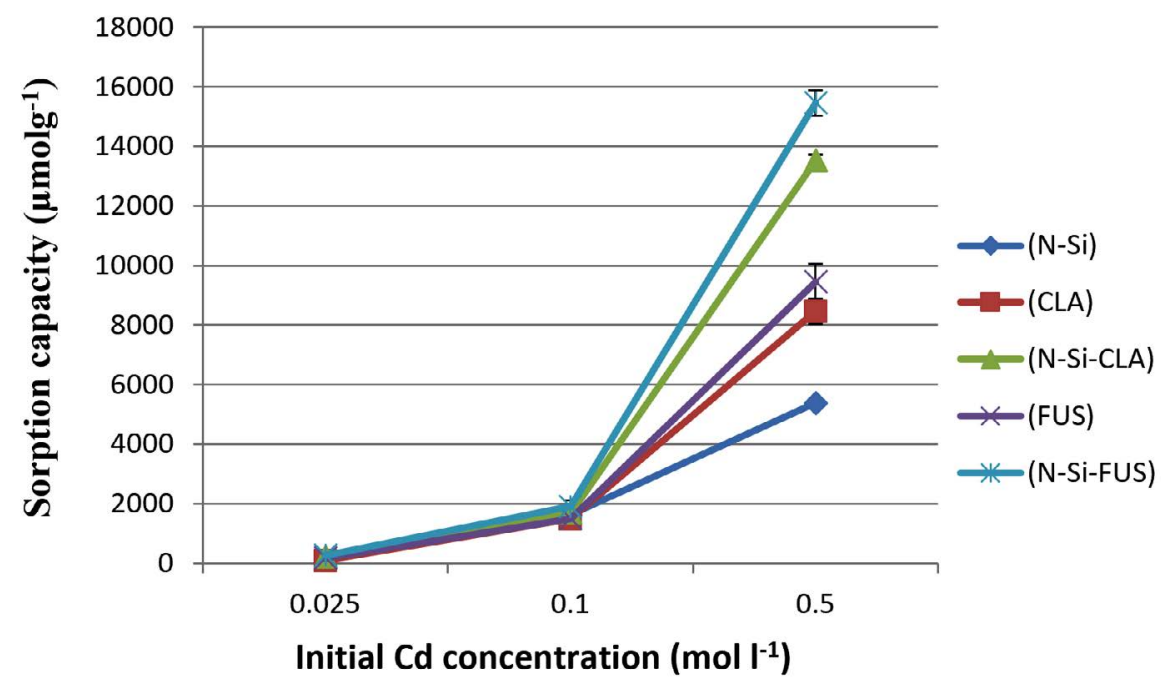

Fig. 5. Effect of initial cadmium concentration on cadmium (II) sorption capacity. ( $\downarrow$ ) Silicon dioxide nanoparticles (N-Si), ( $\mathbf{\square})$ Heat inactivated Cladosporium sphaerospermum (CLA), ( $\boldsymbol{\Delta}$ ) Silicon dioxide nanoparticles combined with heat inactivated Cladosporium sphaerospermum (N-Si-CLA), (X) Heat inactivated Fusarium oxysporum (FUS) and (Ж) Silicon dioxide nanoparticles combined with heat inactivated Fusarium oxysporum (N-Si-FUS) 
Factors affecting $\mathrm{Cd}(\mathrm{II})$ sorption capacity from aqueous solution

Effect of PH on biosorption of Cd(II)

The effect of $\mathrm{pHs}$ of contact solution on cadmium sorption capacity was studied in several solutions with pHs 3.0, 5.0 and 7.0 (Fig 3). The sorption capacity of $\mathrm{Cd}$ (II) recorded the lowest value at $\mathrm{pH} 3$. Sorption was found to be gradually increased as the pHs were increased from 3-7.

Effect of contact period on biosorption of $\mathrm{Cd}$ (II)

It was found that as the contact time of shaking increased from 10 to $30 \mathrm{~min}$, the contact between $\mathrm{Cd}(\mathrm{II})$ and all tested sorbents (N-Si), (CLA),(FUS),(N-Si-CLA) and (N-Si- FUS) was enhanced (Fig 4).

Effect of initial Cd concentration on cadmium sorption capacity

The sorption capacity of $\mathrm{Cd}$ (II) increased as the initial concentration of it has been increased in all sorbents used (Fig 5).

Effect of interference between ions on cadmium sorption capacity

Addition of different salts $(\mathrm{NaCl}, \mathrm{KCl}$ and $\mathrm{CaCl}_{2}$ ) to $\mathrm{Cd}(\mathrm{II})$ aqueous solution indicated that $\mathrm{Ca}^{2+}$ displayed synergistic interfering capability in cadmium ion sorption process comparing to $\mathrm{Na}^{+}$ and $\mathrm{K}^{+}$(Fig 6).

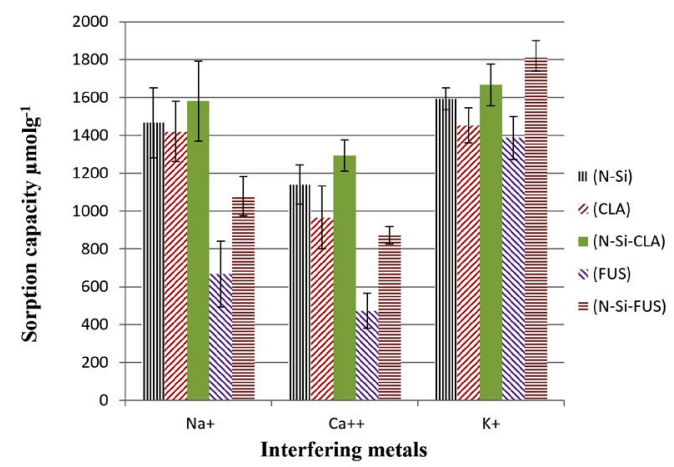

Fig. 6. Effect of metals interference on cadmium (II) sorption capacity. (中) Silicon dioxide nanoparticles (N$\mathrm{Si}),(\square)$ Heat inactivated Cladosporium sphaerospermum (CLA), ( $\square$ ) Silicon dioxide nanoparticles combined with heat inactivated Cladosporium sphaerospermum (N-SiCLA), ( $\nabla$ ) Heat inactivated Fusarium oxysporum (FUS) and (目) Silicon dioxide nanoparticles combined with heat inactivated Fusarium oxysporum (N-Si-FUS)

\section{Bioremediation of cadmium from real waste water samples}

Two waste water samples collected from different factories were amended with different sorbents to study their efficiency in biosorption of Cd(II) (Fig 7). Generally, the sorption capacity of the combined mixtures (N-Si-CLA and N-Si-FUS) achieved higher value than single treatments ( $\mathrm{N}$ $\mathrm{Si}, \mathrm{CLA}$ and FUS). In the first sample, (N-Si-CLA) and (N-Si-FUS) removed $65.73 \%$ and $54.30 \%$ of cadmium, respectively, while $61.33 \%$ and $56.50 \%$ were removed in the second one. The combination mixture of $\mathrm{N}$-Si-CLA proved to be the most potent sorbent for cadmium removal from the two real waste water samples.

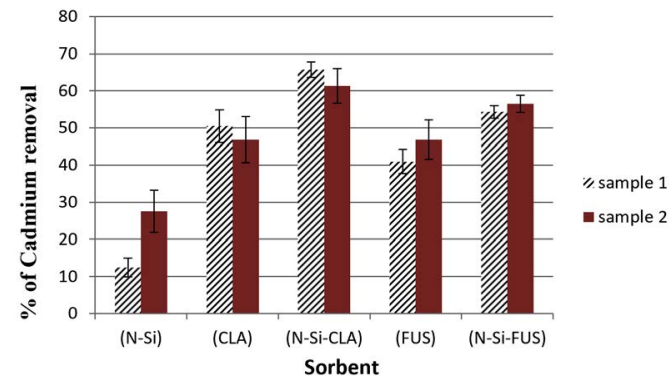

Fig. 7. Application of silicon dioxide nanoparticles (N$\mathrm{Si})$, heat inactivated Cladosporium sphaerospermum (CLA), silicon dioxide nanoparticles combined with heat inactivated Cladosporium sphaerospermum (N-Si-CLA), heat inactivated Fusarium oxysporum (FUS) and silicon dioxide nanoparticles combined with heat inactivated Fusarium oxysporum (N-Si-FUS) for cadmium removal from real waste water. ( $\square$ ) Sample 1 and ( $\mathbf{a}$ ) Sample 2

\section{DISCUSSION}

Few fungal species were isolated from waste water samples. Fungal and bacterial growths were inhibited as a result of the toxic effect of the higher concentration of heavy metals in the tested water samples ${ }^{33,34}$. Although some heavy metals play remarkable roles in physiological, biochemical and metabolic process of living organisms, functioning as co-factors for some enzymes, stability of molecules and regulators of osmotic pressure, most of them has no known biological function in living organisms and are toxic when present in excess ${ }^{35}$. 
In examination of $\mathrm{SiO}_{2}$ particles by FT-IR (Fig 1), bands at $950 \mathrm{~cm}^{-1}$ (peak 8) and $1090 \mathrm{~cm}^{-1}$ (peak 7) were due to $\mathrm{Si}-\mathrm{OH}$ and $\mathrm{Si}-\mathrm{O}-$ $\mathrm{Si}$, respectively (these bands very intense for formation of $\mathrm{SiO}_{2}$ network) ${ }^{36}$. Absorption band at $3600 \mathrm{~cm}^{-1}$ (peak 1) was corresponding to fundamental vibration stretching of different $(\mathrm{OH})$ groups and combination of silicon dioxide located at $1640 \mathrm{~cm}^{-1}$.

By FT-IR observation of fungi, $\mathrm{NH}_{2}$ was found at $3418 \mathrm{~cm}^{-1}$ (peaks 1 and 2 in Fig $1 B$ and $D$, respectively); $\mathrm{CH}$ was found at $2940 \mathrm{~cm}^{-1}$ (peaks 2 and 3 in Fig $1 B$ and D, respectively), Phosphate group was found at $1040 \mathrm{~cm}^{-1}$, (peaks 9 and 10 in Fig $1 B$ and $D$, respectively) and $\mathrm{CO}$ bind $\mathrm{NH}$ to form amide linkage (peak 6) found at $1640 \mathrm{~cm}^{-1} \cdot{ }^{37}$

Fig 1 ( $C$ and $\mathrm{E}$ ) revealed that the peaks specific for individual sorbents were mostly similar to combined (N-Si-CLA) and (N-Si-FUS).

At $\mathrm{pH} 7,(\mathrm{~N}-\mathrm{Si})$ practically achieved higher biosorption capacity than heat inactivated fungal cells of (CLA) and (FUS). This may be due to the presence of silanol group, the large surface area and great porosity expanded to larger number of nanoparticles. The improvement of biosorption capacity of the fungal biosorbents upon combination and immobilization on the surface of silicon dioxide nanoparticles may be due to increasing the surface area of biosorbent subjected to binding with metal ions. Also, the reduction of biosorption at low $\mathrm{pH}$ may be due to the increasing of $\mathrm{H}^{+}$ions which bind to the active binding sites causing Cd(II) sorption inhibition ${ }^{13,38,39}$. Moreover, Saglam et al. ${ }^{40}$ reported that glycoprotein contain phosphate which display negative charges at $\mathrm{pH} 3$ so it affected biosorption significantly. Gadd and White ${ }^{41}$ found that chitin and other proteins on fungal cell wall containing many carboxyl groups.

Rates of adsorption of heavy metal ions via several biosorbents have displayed a broad range of adsorption time. For example, polyvinyl alcohol-yeast and alginate-yeast biosorbent systems used for copper biosorption kinetic studies of 12 -h and 24 -h equilibrium time have been displayed, respectively ${ }^{42}$. The equilibrium time of biosorption of chromium(IV) on the inactivated and immobilized biomass of Rhizopus arrhizus was $2 h^{43}$.
The cadmium biosorption high rates were noticed during the first $48 \mathrm{~h}$ by green micro algae ${ }^{44}$. The biosorption rate of lead on Phanerochaete chrysosporium is rapid and attained saturation during $1 h^{45}$. The equilibrium time of lead biosorption on Aspergillus niger biomass was $5 \mathrm{~h}^{38}$. Cadmium biosorption onto pre-treated biomass of marine alga Durvillaea potatorum was so rapid, $90 \%$ uptake occurred during $30 \mathrm{~min}^{46}$.

Many parameters detect the biosorption rate such as, amount of sorbent, aqueous phase stirring rate, structural properties of biosorbent and support, properties of ion under test, initial ion concentration and presence of other interfering metal ions for the active biosorption sites. So, it is very hard to compare the rates of biosorption reported ${ }^{47,48}$.

There is wide range of sorption capacity of $\mathrm{Cd}(\mathrm{II})$ proportional to initial concentration; for example biosorption capacity by dead Fusarium flocciferum increased with initial concentration ${ }^{49}$.

Different factors controlling the degree affinities of mixed interfering ions on the competitive capacity of sorption such as type of functional groups of microbial cell walls, the kind of charge on ions and the ionic radii ${ }^{19,50}$.

\section{CONCLUSION}

The present study displayed that all tested sorbents were able to remove Cd(II) from waste water. Combined sorbents treatments ( $\mathrm{N}-\mathrm{Si}-\mathrm{CLA}$ and $\mathrm{N}-\mathrm{Si}-\mathrm{FUS}$ ) were proved to be more efficient in $\mathrm{Cd}(\mathrm{II})$ removal from waste water than used singly.

\section{ACKNOWLEDGMENTS}

Great thanks to Dr. Safaa Saeed Mahmoud Hassan Lecturer at Chemistry Department, Faculty of Science, Cairo University for her valuable help and cooperation in applying chemicals and valuable discussions in the practical part of the sorption studies.

\section{CONFLICT OF INTEREST}

The authors declares that there is no conflict of interest 


\section{AUTHORS' CONTRIBUTIONS}

All authors have made substantial contribution to the work and approved it for publication.

\section{FUNDING}

None.

\section{DATA AVAILABILITY}

All datasets generated or analyzed during this study are included in the manuscript and/or the Supplementary Files.

\section{ETHICS STATEMENT}

Not aplicable.

\section{REFERENCES}

1. Barros AJM, Prasad S, Leite VD and Souza AG Biosorption of heavy metals in up flow sludge columns. Bioresour Technol, 2007; 98: 1418-1425. https://doi. org/10.1016/j.biortech.2006.05.044

2. Preetha B and Viruthagiri T. Application of response surface methodology for the biosorption of copper using Rhizopus arrhizus. J. Hazard Mater. 2007; 143: 506-510. https://doi.org/10.1016/j. jhazmat.2006.09.077

3. Ayangbenro SA and Babalola OO. A new strategy for heavy metal polluted environments: A review of microbial biosorbents. Int. J. Environ. Res. Public Health, 2017; 14: 94. https://doi.org/10.3390/ ijerph14010094

4. Lebeau T, Bagot D, J'z'quel K and Fabre B. Cadmium biosorption by free and immobilized microorganisms cultivated in a liquid soil extract medium effects of $\mathrm{Cd}, \mathrm{pH}$ and techniques of culture. Sci. Total Environ., 2002; 291: 73-83. https://doi.org/10.1016/S00489697(01)01093-2

5. Iqbal M, Saeed A and Zafar SI. Hybrid biosorbent an innovative matrix to enhance the biosorption of $\mathrm{Cd}(\mathrm{II})$ from aqueous solution. J. Hazard Mater., 2007; 148: 47-55. https://doi.org/10.1016/j.jhazmat.2007.02.009

6. UK red list substances. Environmental Protection (Prescribed Processes and Substances) Regulations, 1991.

7. US Environmental Protection Agency (USEPA). Integrated Risk Information System (IRIS) on Cadmium, National Center for Environmental Assessment, Office of Research and Development, Washington DC, 1999.

8. Agency for Toxic Substances and Disease Registry (ATSDR). Toxicological Profile for Cadmium, Public Health Service, Department of Health and Human Services, Atlanta, GA, U.S., 2012.

9. Calabrese EJ and Kenyon EM. Air toxics and risk assessment, Lewis Publishers, Chelsea, MI, USA, 1991.

10. US Department of Health and Human Services. Hazardous Substances Data Bank (HSDB, online database), National Toxicology Information Program, National Library of Medicine, Bethesda MD, 1993.
11. Mishra SP. Adsorption-desorption of heavy metal ions. Curr. Sci., 2014; 107: 601-616.

12. Mahmoud ME. Surface loaded 1-methyl-3ethylimidazolium bis (trifluoro methyl sulfonyl) imide [EMIM+Tf2N"] hydrophobic ionic liquid on nano-silica sorbents for removal of lead from water samples. Desalination, 2011; 266: 119-127. https:// doi.org/10.1016/j.desal.2010.08.011

13. Mahmoud ME, Hafez OF, Alrefaay A and Osman MM. Performance evaluation of hybrid inorganic-organic adsorbents in removal and pre concentration of heavy metals from drinking and industrial waste water. Desalination, 2010; 253: 9-15. https://doi. org/10.1016/j.desal.2009.11.044

14. Aksu Z, Sag $Y$ and Kutsal T. The biosorption of $\mathrm{Cu}$ (II) by C. Vulgaris and Z. ramigera. Environ. Technol., 1992; 13: 579-586. https://doi. org/10.1080/09593339209385186

15. Amini M, Younesi $\mathrm{H}$ and Baramifar N. Statistical modeling and optimization of the cadmium biosorption process in an aqueous solution using Asepergillus niger. Colloids Surf. A., 2009; 337: 67-73. https://doi. org/10.1016/j.colsurfa.2008.11.053

16. Barkay $T$ and Schaffer J. Metal and radionuclide bioremediation. Curr. Opin. Microbiol., 2001; 4: 318323. https://doi.org/10.1016/S1369-5274(00)00210-1

17. Chergui A, Bakhti MZ, Chahboub A, Haddoum S, Selatnia A and Junter GA. Simultaneous biosorption of $\mathrm{Cu}^{2+}$, $\mathrm{Zn}^{2+}$ and $\mathrm{Cr}^{6+}$ from aqueous solution by Streptomyces rimosus biomass. Desalination, 2007; 206: 179-184. https://doi.org/10.1016/j.desal.2006.03.566

18. Sar P and D'Souza SF. Biosorption of thorium(IV) by a Pseudomonas biomass. Biotechnol Lett, 2002; 24: 239-243. https://doi.org/10.1023/A:1014153913287

19. Wang Y, Gao H, Sun J, Li J, Su Y, Ji Y and Gong C. Selective reinforced competitive biosorption of $\mathrm{Ag}$ (I) and $\mathrm{Cu}$ (II) on Magnetospirillum gryphiswaldense. Desalination, 2011; 270: 258-263. https://doi.org/10.1016/j. desal.2010.11.053

20. Immamuglu M and Tekir O. Removal of copper(II) and lead(II) ions from aqueous solutions by adsorption on activated carbon from a new precursor hazelnut husks. Desalination, 2008; 228: 108-113. https://doi. org/10.1016/j.desal.2007.08.011

21. Tangjuank S, Insuk N, Tontrakoon J and Udeye V. Adsorption of lead (II) and Cadmium (II) ions from aqueous solutions by adsorption on activated carbon prepared from cashew nut shells. Int. J. Chem Mol Eng, 2009; 3: 221-227.

22. Liu Q, Zheng $\mathrm{T}$, Wang $\mathrm{P}$, Jiang J and Li N. Adsorption isotherm, kinetic and mechanism studies of some substituted phenols on activated carbon fibers. J. Chemical Engineering, 2009; 157: 348-356. https:// doi.org/10.1016/j.cej.2009.11.013

23. Shannon M, Bohn PW, Elimelech M, Georgiadis JG, Marinas BJ and Mayes AM. Science and technology for water purification in the coming decades. Nature, 2008; 452: 301-310. https://doi.org/10.1038/ nature06599

24. Anastasios Al, Zouboulis KA, Loukidou M and Sebaesta F. Metal biosorption by PAN immobilized fungal biomass in simulated wastewaters. Colloids Surf. A., 
2003; 212: 185-195. https://doi.org/10.1016/\$09277757(02)00304-7

25. Baik WY, Bae JH, Cho KM and Hartmeier W. Biosorption of heavy metals using whole mold mycelia and parts of thereof. Bioresour. Technol., 2002; 81: 167-170. https://doi.org/10.1016/S0960-8524(01)00148-1

26. Beolchini F, Pagnaneli F, Esposito $A$, Toro $L$ and Veglio F. Biosorption of copper by Sphaerotilus natans immobilized in poly sulfone matrix: Equilibrium and kinetic analysis. Hydrometallurgy, 2003; 70: 101-112. https://doi.org/10.1016/S0304-386X(03)00049-5

27. Pandey AK, Pandey SD, Misra V and Devi S. Role of humic acid entrapped calcium alginate beads in removal of heavy metals. J. Hazard Mater., 2003; 98: 177-181. https://doi.org/10.1016/S03043894(02)00316-3

28. Yun-guo L, Ting F and Guang-ming Z. Removal of cadmium and zinc ions from aqueous solution by living Aspergillus niger. Trans Nonferrous Met. Soc. China, 2006; 16: 681-686. https://doi.org/10.1016/ S1003-6326(06)60121-0

29. Tsekova K, Todorova D and Ganeva S. Removal of heavy metals from industrial wastewater by free and immobilized cells of Aspergillus niger. Int. Biodeterior and Biodegrad, 2010; 64: 447-451. https://doi. org/10.1016/j.ibiod.2010.05.003

30. Jung $\mathrm{H}, \mathrm{Xu} F$ and Li K. Purification and characterization of laccase from wood degrading fungus Trichophyton ruburn LKY-7. Enzyme Microb Technol, 2002; 30: 161168. https://doi.org/10.1016/S0141-0229(01)00485-9

31. Moubasher AH. 1993. Soil fungi in Qatar and other Arab countries, The Center for Scientific and Research, University of Qatar, Qatar.

32. Mahmoud ME, Yakout AA, Abdel-Aal H and Osman MM. Enhanced biosorptive removal of cadmium rom aqueous solutions by silicon dioxide nano-powder, heat inactivated and immobilized Aspergillus ustus. Desalination, 2011; 279: 291-297. https://doi. org/10.1016/j.desal.2011.06.023

33. Malik A. Metal bioremediation through growing cells. J Environ Intern, 2004; 30: 261-278. https://doi. org/10.1016/j.envint.2003.08.001

34. Rama-Rao VSKV, Akhtar N and Maruthi MP. Isolation of a cadmium tolerant Curvularia sp. for polluted effluent. Curr. Sci., 1997; 73: 453-455.

35. Fashola $M$, Ngole-Jeme $V$ and Babalola O. Heavy metal pollution from gold mines: Environmental effects and bacterial strategies for resistance. Int $\mathrm{J}$. Environ. Res. Public Health, 2016; 13: 1047. https:// doi.org/10.3390/ijerph13111047

36. Guibal E, Roulph C and Cloirec PL. Infrared spectroscopic study of uranyl biosorption by fungal biomass and materials of biological origin. Environ. Sci. Technol., 1995; 29: 2496-2502. https://doi.org/10.1021/ es00010a007

37. Kapoor A and Viraraghavan T. Heavy metal biosorption sites in Aspergillus niger. Bioresour. Technol., 1997; 61: 221-227. https://doi.org/10.1016/S09608524(97)00055-2
38. Kapoor A, Viraraghavan T and Cullimore DR. Removal of heavy metals using the fungus Aspergillus niger. Biores Technol, 1999; 70: 95-104. https://doi.org/10.1016/ S0960-8524(98)00192-8

39. Reed BE and Arunachalamn S. Use of granular activated carbon columns for lead removal. J. Environ. Eng., 1994; 120: 416-436. https://doi.org/10.1061/ (ASCE)0733-9372(1994)120:2(416)

40. Saglam N, Yalcinkaya Y, Denizli A, Arca MY, Genc O and Bektas S. Biosorption of mercury by carboxy methylcellulose and immobilized Phanerochaete chrysosporium. J. Microchem., 2002; 71: 73-81. https://doi.org/10.1016/S0026-265X(01)00142-4

41. Gadd GM and White C. Microbial treatment of metal pollution-a working biotechnology?. Trends Biotechnol., 1993; 11: 353-359. https://doi. org/10.1016/0167-7799(93)90158-6

42. Ting YP and Sun G. Use of polyvinyl alcohol as a cell immobilization matrix for copper biosorption by yeast cells. J. Chem. Technol. Biotechnol., 2000; 75: 541-546. https://doi. org/10.1002/1097-4660(200007)75:7\%3C541::AIDJCTB247\%3E3.3.CO;2-0

43. Prakasham RS, Merrie JS, Sheela R, Saswathi N and Ramakrishna SV. Biosorption of chromium(VI) by free and immobilized Rhizopus arrhizus. Environ. Pollut., 1999; 104: 421-427. https://doi.org/10.1016/S02697491(98)00174-2

44. Sobhan R and Sternberg SPK. Cadmium removal of Cladophora. J. Environ. Sci. Health, 1999; 34: 53-72. https://doi.org/10.1080/10934529909376823

45. Yetis U, Dolek A, Dilek FB and Ozcengiz G. The removal of $\mathrm{Pb}$ (II) by Phanerochaete chrysosporium. Water Res., 2000; 34: 4090-4100. https://doi.org/10.1016/S00431354(00)00155-X

46. Matheickal JT, Yu Q and Woodburn GM. Biosorption of cadmium(II) from aqueous solution by pre-treated biomass of marine algae Durvillaea potatorum. Water Res., 1999; 33: 335-343. https://doi.org/10.1016/ S0043-1354(98)00237-1

47. Bayramoglu G, Tuzun I, Celik G, Yilmaz M and Arica MY. Biosorption of Mercury (II), Cadmium (II) and Lead (II) ions from aqueous system by microalgae Chlamydomonas reinhardtii immobilized in alginate beads. Int J Miner Process, 2006; 81: 35-43. https:// doi.org/10.1016/j.minpro.2006.06.002

48. Genc ", Yaleinkaya Y, B y ktuneel E, Denizli A, Arica $M Y$ and Bektas $S$. Uranium recovery by immobilized and dried powdered biomass: characterization and comparison. Int. J. Miner Process, 2003; 68: 93-107. https://doi.org/10.1016/S0301-7516(02)00062-5

49. Delgado A, Anselmo AM and Novais JM. Heavy metal biosorption by dried powdered mycelium of Fusarium flocciferum. Water Environ. Res., 1998; 70: 370-375. https://doi.org/10.2175/106143098X125019

50. Yan $\mathrm{G}$ and Viraraghavan T. Heavy-metal removal from aqueous solution by fungus Mucor rouxii. Water Res., 2003; 37: 4486-4496. https://doi.org/10.1016/S00431354(03)00409-3 